\title{
Case finding in the elderly: does the primary care team already know enough?
}

\author{
Judith Hooper
}

\begin{abstract}
The needs of an elderly population in one general practice were assessed by the primary health care team. A simple questionnaire was filled in as far as possible by members of the team on known social and functional criteria for each patient aged over 75 . The questionnaire was complete for 100 of 118 elderly patients. The information was accurate for over $95 \%$ of the criteria as verified by information held by the health authority. This information will now be used for yearly reviews of each patient based on opportunistic contacts.

This is a simple method of collating information that is already known. If such information was available to health authorities it would give them an idea of the type and extent of the support services needed for elderly people.
\end{abstract}

\section{Introduction}

There is considerable interest in the care of elderly people in the community, particularly as the population aged over 85 years is expected to double in the next 25 years. ' The government has encouraged "doctors to provide comprehensive regular care for elderly people." This is reinforced in the Griffiths report, ${ }^{2}$ which emphasises the key role of primary health care in caring for groups at risk.

Many published papers describe methods of assessing the needs of the elderly in primary health care. Some methods entail screening for unmet needs. ${ }^{3.5}$ Among the schemes described are detailed interview questionnaires, ${ }^{3-5}$ brief postal surveys, ${ }^{6}$ and opportunistic case finding. ${ }^{78}$ Many of these take a lot of time to carry out and often are done by a highly motivated member of the primary health care team. Simpler methods have also been described, ${ }^{9}$ such as the use of an age-sex register and holding regular team meetings to monitor the contacts with the elderly population and to plan programmes for care. There is no overall consensus that screening is worth while, ${ }^{10}$ and it is difficult to identify risk factors ${ }^{11}$ for case finding. ${ }^{12}$

We thought that as a primary health care team we had considerable knowledge of our elderly population and that this information would be far more useful if it was collected on a summary card in the patient's notes. We thought that there were few elderly patients of whom we were unaware. ${ }^{13}{ }^{14} \mathrm{We}$ also thought that this could be the basis for a continuing programme of care using this database, which would be a simple system that did not require the efforts of a highly motivated team member.

To be useful the information had to be accurate, and we were fortunate in being able to verify this. Newcastle Health Authority has a Care Team for the Elderly which screens all people aged over 75 in the area. Thus we checked our data against theirs.

Our aims were $(a)$ to discover how much our primary health care team knew already about our patients over 75 without carrying out any specific assessment; $(b)$ to determine how accurate this information was; $(c)$ to share and increase the knowledge of the primary health care team about this group of patients through the use of a summary card kept in the medical record; $(d)$ to identify patients' needs by closer liaison between members of the primary health care team.

\section{Method and results}

The checklist of criteria consisted of a card which fitted into the standard general practice medical envelope (Lloyd George size). The list covered social details (table I), services provided (table II), and functional assessment of mobility, self care tasks, incontinence, and sensory and mental state (table III and IV).

Patients who were over 75 were identified from our age-sex register. We attempted to complete the checklists in a series of team meetings, but it was often easier for team members to complete the card individu-
Department of Family and Community Medicine, University of Newcastle upon Tyne, Medical School, Newcastle upon Tyne NE2 4HH Judith Hooper, MRCGP, lecturer in family medicine
TABLE I-Details known about social aspects of 118 elderly patients

\begin{tabular}{lcccccrrr}
\hline & $\begin{array}{c}\text { Next of } \\
\text { kin }\end{array}$ & $\begin{array}{c}\text { Lived } \\
\text { alone }\end{array}$ & $\begin{array}{c}\text { Lived with } \\
\text { carer }\end{array}$ & $\begin{array}{c}\text { House } \\
\text { ownership }\end{array}$ & Toilet & Heating & $\begin{array}{c}\text { Social } \\
\text { contacts }\end{array}$ & $\begin{array}{c}\text { Supplementary } \\
\text { pension }\end{array}$ \\
\hline $\begin{array}{l}\text { Primary health care team: } \\
\quad \text { Knew }\end{array}$ & 103 & 106 & 93 & 103 & 106 & 98 & 93 & 24 \\
$\quad$ Was incorrect & 1 & 1 & 1 & 1 & 2 & 2 & 1 & 32 \\
\hline
\end{tabular}

TABLE II - Details known about services provided for 118 elderly patients

\begin{tabular}{lcccccc}
\hline & District nurse $^{\star}$ & Home help & Meals on wheels & Chiropody & Geriatric care & Psychiatric caret \\
\hline $\begin{array}{l}\text { Primary health care team: } \\
\text { Knew }\end{array}$ & 84 & 80 & 71 & 63 & 90 & 91 \\
Was incorrect & 1 & 10 & 4 & 4 & 0 & 0 \\
\hline
\end{tabular}

^This includes district nurse, health visitor, and bath attendant.

†Outpatient or community nurse care. 
TABLE III-Details known about functioning levels of 118 elderly patients

\begin{tabular}{|c|c|c|c|c|c|c|c|c|c|c|}
\hline (a) & $\begin{array}{l}\text { Goes out } \\
\text { alone }\end{array}$ & $\begin{array}{l}\text { At risk } \\
\text { of falls }\end{array}$ & $\begin{array}{l}\text { Uses } \\
\text { stairs }\end{array}$ & Chairbound & $\begin{array}{l}\text { Can } \\
\text { bath }\end{array}$ & $\begin{array}{l}\text { Cuts } \\
\text { toenails }\end{array}$ & Cooks & $\begin{array}{l}\text { Personal } \\
\text { hygiene }\end{array}$ & $\begin{array}{l}\text { Adequacy } \\
\text { of clothing }\end{array}$ & $\begin{array}{l}\text { State of } \\
\text { skin }\end{array}$ \\
\hline \multicolumn{11}{|c|}{ Primary health care team: } \\
\hline Knew & 100 & 106 & 110 & 91 & 110 & 109 & 109 & 117 & 113 & 115 \\
\hline Was incorrect & 0 & 1 & 1 & 0 & 5 & 11 & 5 & 1 & 0 & 0 \\
\hline (b) & \multicolumn{2}{|c|}{ Vision } & Hearing & \multicolumn{2}{|c|}{ Bladder } & Bowels & Weight & \multicolumn{2}{|c|}{ Diet } & Dentition \\
\hline \multicolumn{11}{|c|}{ Primary health care team: } \\
\hline Knew & \multicolumn{2}{|r|}{113} & 113 & \multicolumn{2}{|c|}{114} & 114 & 116 & \multicolumn{2}{|c|}{114} & 111 \\
\hline Was incorrect & & 5 & 7 & \multicolumn{2}{|c|}{1} & 0 & 4 & & 1 & 5 \\
\hline
\end{tabular}

TABLE IV-Details known about mental state of 118 elderly patients

\begin{tabular}{lcccrrr}
\hline & Memory & Disorientation & Depression & Lonely & Alcohol abuse & At risk \\
\hline $\begin{array}{l}\text { Primary health care team: } \\
\text { Knew }\end{array}$ & 108 & 107 & 106 & 106 & 105 & 104 \\
Was incorrrect & 1 & 2 & 3 & 2 & 0 \\
\hline
\end{tabular}

TABLE V-Sources of information within the team

\begin{tabular}{lccccc}
\hline & & & Functioning levels & \\
\cline { 3 - 5 } & Social data & Services provided & (a) & (b) & Mental state \\
\hline Receptionists & 59 & 2 & 12 & 86 & 14 \\
Nursing staff & 10 & 17 & 13 & 0 \\
General practitioners & 37 & 72 & 101 & 24 & 94 \\
\hline
\end{tabular}

ally. Our primary health care team consisted of district nurses, general practitioners, health visitor, practice nurse, and reception staff. The notes contributed by each group were colour coded so an assessment could be made of each contribution. Details on functional assessment were coded according to previously agreed criteria to avoid idiosyncratic interpretation.

The health authority's care team then carried out a full screening procedure on the study group. They corrected our checklists for inaccuracies from the information they had.

Our age-sex register of 4100 patients had $329(8 \%)$ people over age 75 . Of these, 56 were in homes for the elderly so we excluded them from the study, considering that their needs were different from those of people who lived at home.

Because of lack of time we took a random sample to limit the number of patients in the study group. The primary health care team could complete only 15 checklists a week either in meetings or individually. To avoid bias we completed our assessments before the health authority team started theirs. It was important that the two assessments were carried out at about the same time so the study group comprised initially one half of the remaining 273 persons. The health authority care team could not assess nine patients as they were not at home, and a further nine died during the study period of three months. The study group eventually consisted of 118 patients.

\section{HOW MUCH DID WE KNOW}

Tables I-IV list the criteria and give the numbers of patients for whom the primary health team knew details. There was one patient only about whom we knew nothing. The results show that our main area of ignorance was about other agencies concerned in the care of the patient (table II). This applied to health services as well as social services. In particular our lack of knowledge about any involvement with churches and religious groups is unfortunate as so often they have excellent visiting groups who provide considerable support. The district nurse category should have been completed by either the district nurse or health visitor. They were unable to complete all the cards owing to lack of time.
HOW ACCURATE WERE WE?

Despite criteria being agreed the statements about function (tables III and IV) are subject to idiosyncratic variation and obviously do not represent a formal assessment. The health authority team agreed with over $95 \%$ of our data for six criteria (excepting cutting toenails) and agreed with $99 \%$ of our data for the remainder (tables I and II).

\section{WHO WERE THE SOURCES OF INFORMATION?}

The doctors gave most of the information (table V), irrespective of type. This is not surprising as they see the elderly patients at home as well as in the surgery. The receptionists knew only those who came to the surgery, but they knew social details for about half of the patients. They also made statements about functioning for 86 patients and certainly were aware of all those who were at risk. The district nursing staff knew details about 20 patients $(17 \%)$. They were caring for 17 , as they are concerned in caring only for patients who do not come to the surgery. These data are not entirely accurate as the receptionists usually completed the card first, though other members of the team may also have had the information.

\section{Where next?}

As the interest in community care of elderly people grows the focus must be on providing care to improve function. A great problem facing authorities in planning such care is knowing where services are needed, how many people need formal services, and what type of and to what extent formal services are required.

There is a dilemma in planning services from the identification of population needs. Large scale screening is expensive and takes time, so the results may be out of date before they are published. Over the years there has been much discussion about case finding or screening the elderly population for unmet need. ${ }^{3 \cdot 12}$ Recently it has been shown that non-consulters do not need help. ${ }^{13}{ }^{14}$

Primary health care in the United Kingdom is in a unique position to identify needs because (i) $99 \%$ of the population is registered with a general practitioner, (ii) 
$93 \%$ of the population over 75 contact their general practitioner every year, ${ }^{15}$ (iii) a continuous personal medical record is kept, $(i v)$ there is a multidisciplinary team, and $(v)$ the primary health care team has a continuing responsibility to their patients and so can maintain a continuous case finding programme.

To maximise the potential of primary health care and to help those who plan services a universal system of identifying people and their needs is required which is simple, acceptable, and accurate. Because primary health care teams have considerable contact with their elderly patients they also have considerable knowledge of this group.

In using a simple method to collate information about our patients we have shown that only one patient out of 118 was entirely unknown to our team. We knew over 100 people sufficiently well to complete the questionnaire for virtually all 32 social and functional criteria. We were inaccurate for less than $5 \%$ of the functional criteria for this group. A formal assessment of these patients had not been made by us so we had to make some assumptions about functioning level.

Our practice now carries out a yearly review of all of our elderly patients using this checklist. Each year during the patient's month of birth the checklist for that patient is discussed at a meeting of the primary health care team. If there is any concern about the patient or the checklist is thought to be inaccurate a member of the team is nominated to contact the patient. Otherwise the checklist is left in the medical folder and updated or completed with the patient (during the following year, if possible) at any opportunistic contact. The extra work for the team is the monthly meeting.

Our system of collating information which the primary health care team already knows about their elderly patients is simple and accurate, particularly if the checklists are updated by opportunistic review. So before primary health care teams embark on formal programmes of care for elderly patients they should feel encouraged to collate such information. Those who plan services for the elderly could benefit greatly from such a database of functional disability that can be updated. The advantages are obvious to patients, carers, and professionals.

I thank my own primary health care team and the health authority team for their enthusiastic cooperation and support.

1 Secretary of State for Social Services, Wales, Northern Ireland Scotland. Promoting better health. London: HMSO, 1987:para 3.17. (Cmnd 249.)

2 Griffiths R. Community care: agenda for action. London: HMSO, 1988:para $4.16,6.14$.

3 Freedman GR, Charlewood JE, Dodds PA. Screening the aged in general practice. $\mathcal{F}$ R Coll Gen Pract 1978;28:421-5.

4 Barber JH, Wallis JB. Assessment of the elderly in general practice. $f \mathrm{R}$ Coll Gen Pract 1976;26:106-14.

5 Tulloch AJ, Moore VL. A randomised controlled trial of geriatric screening and surveillance in general practice. I R Coll Gen Pract 1979;29:733-92.

6 Barber JH, Wallis JB, McKeating E. A postal screening questionnaire in preventive geriatric care. $7 R$ Coll Gen Pract 1980;30:49-51.

7 Dr Stringfellow's Team. Prevention for patients over 75 : is it worth the bother? BrMed f 1986;292:1243-4.

8 Freer CB. Consultation-based screening of the elderly in general practice; a pilot study. F R Coll Gen Pract 1987;37:455-6.

9 Woods JO, Parthen MP, Reilley PM. Primary care teams and the elderly in Northern Ireland. $\mathcal{I} R$ Coll Gen Pract 1983;33:693-7.

10 Freer $\mathrm{CB}$. Geriatric screening: a reappraisal of preventive strategies in the care of the elderly. I $R$ Coll Gen Pract 1985;35:288-90.

11 Taylor RC, Ford EG. The elderly at risk - a critical examination of commonly identified groups. F $R$ Coll Gen Pract 1983;33:699-705.

12 Williamson J. Screening, surveillance and case finding. In: Arie $T$, ed. Health care of the elderly. London: Croom Helm, 1981.

13 Ford $\mathrm{G}$, Taylor $\mathrm{R}$. The elderly as underconsulters: a critical appraisal. $\mathcal{f} R \mathrm{Coll}$ Gen Pract 1985;35:244-7.

14 Ebrahim S, Hedley R, Sheldon M. Low levels of ill health among elderly nonconsulters in general practice. Br Med f 1984;289:1273-5.

15 Williams EI. Characteristics of patients over 75 not seen during one year in general practice. Br Med f 1984;288:119-21.

(Accepted 14 October 1988

MULTICULTURAL MEDICINE

\section{See the error of their ways}

The Asians have three things in common with the Irish: they believe that everything, but everything, happens by the Will of God (Bhagwan or Allah); they serve larger portions of food and second helpings of meat only to men at a dinner; they are very reliable but hardly ever punctual for a meeting. On the other hand, the English are almost always punctual because timekeeping, as sitting on committees and standing in queues, is part of their national character. Asian and English doctors are very polite when face to face, but behind each other's backs they laugh at each other. It is not uncommon for an individual from one ethnic group to say what someone from the other group wants to hear, rather than the truth, to avoid embarrassment. If, however, that individual is asked sympathetically without any hint of denigration, the truth will be told.

The Queen gave a banquet on the royal yacht Britannia after a conference for the heads of states of the Commonwealth. Most guests arrived on time, but eight leaders-Mr Rajiv Gandhi (a Hindu) and seven Africans (Moslems and Catholics) - arrived an hour late. Queen Elizabeth is not used to waiting for anyone! She paced up and down, looking very angry (and perhaps feeling very hungry), and was relieved - not pleasedwhen they finally arrived. The British press were delighted to cover the story for public amusement. The British were amazed and some Labour MPs speculated that this late arrival was an intentional mischief. Sales of newspapers reached their peak that day but no one knew the reason why these guests were late and, worse still, except for saying "sorry," they gave no excuse. Perhaps it is a well guarded secret that for Hindus, Moslems, and Catholics sunset prayer, in a nearby temple, mosque, or church, is more important than attending a royal feast given by the head of a Protestant faith, even the Queen. They believe that their might is a gift from the Almighty and, as with "Oliver," ask for more!

A group of delegates from the British doctors' association went to Delhi to attend a meeting with eminent Indian doctors. They stayed in a five star hotel, and after enjoying an English breakfast served by Hindu waiters they arrived at the conference room at the stated time $-9 \mathrm{am}$. They were almost awake but had a surprise when they did not see any of their hosts, just a sleepy peon. The Indian delegates arrived at $10 \mathrm{am}$ and no apology was offered. When forced into a corner the Indian chairman apologised by saying that the time $(9 \mathrm{am})$ was a misprint on the programme. Afterwards, in private he told his British counterpart that it is a Hindu custom to get up early in the morning, walk to the river Jamna for ashnan (bathing, not swimming), and then go to the temple before going to work. In a temple the Pandit takes his time in his rituals and therefore none of the faithful feels guilty about being late for work because they can't leave until the prayers are finished. That day the conference did not finish on time either. The leader of the British delegation, a Conservative, had to listen to speeches of Indian doctors publicly attacking each other and this reminded him of Labour party conferences at home. It is fair to say that, being a socialist democracy, it is customary in India for members of a delegation with opposing views to wash their dirty linen in public.

No so long ago, the president of an English royal college attended the dinner at the annual general meeting of an Irish college in Dublin. At $7 \mathrm{pm}$ the only person he saw was an anglicised Asian doctor, but there was no sign of an Irishman. At 7 45, however, almost everyone arrived and all had a good time. On his return to London he mentioned the occurrence to his small primary care team. A Polish receptionist rationalised by saying that perhaps the Irish doctors went to church for evening mass, but an Irish nurse remarked, "Not really, they must have gone to a pub." The English president wondered if both of them were right.

In an international contact or in a consulting room when a patient comes from another culture things will be different. People may pretend otherwise but can never abandon their cultural or religious habits and can't change their ethnicity anyway. With mutual understanding a compromise can be reached. Don't take things for granted and mind how you go.BASHIR QURESHI, general practitioner, Hounslow, London 